\title{
MAKING COMPUTING AVAILABLE
}

\author{
Norman Sanders \\ Formerly at the Computing Centre, The Norwegian Technical University, Trondheim, \\ Norway; Norman_Sanders@compuserve.com
}

\begin{abstract}
The Computing Centre of the Norwegian Technical University was established in January 1963, with a staff of 1.5 people and a small Danish computer, GIER. By mid-1965, it had grown to a staff of 25 with a large-scale computer, using the computing facilities at night as a service bureau to pay salaries. Training courses were instituted into the established schedule; operations were made highly efficient; real-life applications contributed to a non-academic appreciation of computers; the computing service was spread all across the campus, and many people had a lot of fun.
\end{abstract}

Key words: University computing, computer management, training, pioneering, GIER

\section{INTRODUCTION}

This seminar is about using computers, and we are hearing about an impressive range of applications that were developed as early as fifty years ago during the Golden Age of Computers. From the very start there seemed to be no limit to the ideas that computers spawned - mathematics, engineering, manufacturing, finance, management and so on. No one was in charge. No one pontificated on what we should or should not do. Everyone with an idea was welcome on board; you did not need any formal qualifications. All you needed to do to get it all going was to make the computer available, and this is what we tried to do here at Norges Tekniske Høgskole (NTH) as with all the other organisations represented here these days. 
However, how do you make a computer available? One way might be to open the computer room door and announce to anyone who might be passing, "Roll up folks; here it is. Just come on in and make yourself at home. Last one to finish locks up and drops the key through my front door". That's one way of making computers available. Though often used in those days, it's known as the not terribly brilliant way of running a computing centre, so we tried something different.

This talk is about how we did it, in our own sweet way, as opposed to how anyone else might have done it. The details depended very much on our particular circumstances, the way NTH was organised, the people involved, their academic interests, and so on. Moreover, since I was ultimately responsible for trying to bring the many varied interests together, this talk is inevitably rather personal, starting by stating that I had never been to Trondheim before, could not speak the language, did not know anything about the structure of NTH, its culture, or its members. I knew absolutely nothing and was therefore admirably suited to the job.

\section{THE BEGINNINGS}

I arrived in Trondheim on a very cold January day in 1963, straight from Seattle via Los Angeles, without a stitch of warm clothing. The computer was Danish. It had $1 \mathrm{~K}$ words of core, a 12,800-word drum, no tape or printer; and it had a wooden door. I thought it was the broom closet. It had an Algol compiler, but I was a FORTRAN man. The staff consisted of a secretary, Sidsel Rom, and a post-graduate, Knut Skog, who was just about to leave. I had only known one Norwegian before my arrival, Ole Hestvik of the Control Engineering Department. It was overall a sobering prospect.

I was on leave of absence from Boeing, and was expected to return by April 1965. By that time, however, Regnesentret had become an establishment of about 25 people, with a giant Univac 1107 on its way (so we thought) from St. Paul, Minnesota, and computing had spread all over Gløshaugen and down into the town. It was an explosive two years!

I don't think, however, that the youngsters of today are a bit interested. Computing today is as available as the air they breathe. It comes as some God-given right and is literally at their fingertips, as it should be. This is indeed what we were striving for right from the start. Nevertheless, I think a great deal of the fun was in getting it that way. I don't think that many people today know what a computer is. Indeed, the irony is that the larger and more complicated the computer, the simpler the things we do with it. A secretary could not have used Cambridge University's 1949 1K EDSAC to type a letter, but it helped discover the shape of DNA. Language facilities 
and software generally are so powerful today that hardly anyone needs to know the concepts of a bit, a word, an instruction, an exponent, a floating point number, an index register or an overflow indicator - and rightly so. But there goes the fun. On the other hand why should computers be fun? They are too expensive. Nevertheless, the "Golden Age" was fun.

So how do you start? You have something that looks like a broom closet, a secretary and a solitary computer man just about to call in the movers. The whole thing is being organised by an on-campus research institute called SINTEF on behalf of the university because the latter didn't have the structure to do it itself. You have no budget apart from the secretary's salary and half yours. There is no provision for any courses on the schedule. All input is via punched paper tape; that is, every program change means an entire recopying of the tape instead of a one-card insertion. There are seven Flexowriters at which sit seven users making seven times seven errors per minute. The professor of Numerical Analysis is from Germany and his English is hardly better than your Norwegian. There is no printer. Output is by punched tape, to be printed later character by character on the Flexowriters. Something called a carrousel was on order from Denmark consisting of 128 mini-magnetic tapes on a rotating wheel, highly reminiscent of a fairground. Moreover, Algol to you is as a red rag is to a bull.

We have arrived at the fairground. Since you never get a second chance to make a first impression, I create a seven-digit job number system on Day One. (Whenever you are at a loss for something to do, just start a sevendigit job number system. It won't get you a Nobel Prize but it will pay off sooner than you think.) However, there are two glimmers of real hope. The first is that no one actually expects anything, so no matter how much you muck it up no one will ever know. Secondly, here and there in this and that niche were people who had already acquired considerable experience on the computer. If we could bring about a balanced hardware configuration, close the shop and give some courses, in five years we might develop ourselves into a computing centre.

\section{USING THE "GIER" COMPUTER}

Among the primeval users of GIER (as the machine was called) were the structural engineers in Professor Holand's institute, Professor Borgen's chemists (who used to sleep on the computer room floor) and Professor Balchen's control engineering boys. Indeed, the latter had been largely responsible for building the machine at Dansk Regnesentral in Copenhagen. Here I would like to pay an especial tribute to Nils Ivar Bech, whose 
generosity and helpfulness made it possible to acquire the computer. We shall find out that GIER was a far smarter move than I had originally thought, as the vastness of the $32 \mathrm{~K}$ of the IBM 7090s that I had left behind at Boeing had blinded me.

The first thing to do seems to be to put the actual hardware in the hands of full-time operators; this is the only way of getting any efficiency out of it. However, efficiency on the computer itself does not mean much at first because so little work is reaching it largely because of the lack of skill of the users at the keys of the Flexowriters. So before that we need to hire some secretaries to operate the Flexowriters. However, you cannot do this because you have no money to pay them. Where on earth do you start?!

A ray of hope, however, was the university's decision to let me use the night shift as a sort of private computer services company. But to do that we needed some staff, a chicken-and-egg catch-22 situation. If you can earn money on night shift, you can hire staff. But, how can you earn money if you don't have any staff in the first place? To prime the pump they let me keep Knut Skog. I remember he was on Kr. 32,000 per annum, but where the money came from I simply don't recall. (Probably Karl Stenstadvold sold a violin.)

Step zero, then, is to bring in some work from the big wide commercial world. But how do you talk to people about their computer problems when they don't know what a computer is? (How do you talk to the blind about colour?) Somehow, we managed it. The roll of honor of those two first years reads somewhat as follows: Sausage Helgesen, The Norwegian Fisheries, The Norwegian Geological Survey, The Institute of Statistics at the University of Uppsala (we went international right from the start), an oil company, a cement factory, a chemical company, a mapping company, a mining company, the farmers' cooperative and several others. Think of it! They actually trusted our computer and us. Nevertheless, we delivered the goods, on time and within budget - we had to. Such on-time performance is a rare occurrence now with its virtually infinite machine capacities and highfalutin languages and data structures! We were probably the only university computing centre in the world in the service bureau business. We were at least as good as any commercial outfit and without those wonderful customers, there would never have been a university computing centre as we knew it. The government did not provide the funding that we needed to make the centre viable. The individual private companies and institutions made it all possible by rewarding hard work performed well into the small hours. (Fortunately, we did not have any government working regulations in those days destroying our enthusiasm and preventing us getting the job done.) 
In addition to the income, the commercial work served to teach these fresh graduates, and sometimes their professors, something about the real world. The experience crept into the lectures and often spawned careers.

However, not all this happened over night; hiring people had to go hand in hand with getting jobs. At first, we hired three women to do the keypunching. Immediately a wave of work started hitting the computer and the bottleneck moved to the printer. It was now Easter, so we flew down to see Bech in Copenhagen. What we needed was a high-speed printer, which we could buy with the carrousel money. But, that was not legal; it had to be an official Norwegian government order. OK, so they sent us a printer but billed us for a carrousel. Mission accomplished!

When we got back, there was an outcry. Poor Professor Romberg; he had set his heart on the carrousel. His pockets were bulging with mini tapes. With all those data in the computer and no way of getting it out, it would have been a case of "data constipation" without equal. When the printer arrived (and 20 characters per second became a thousand lines a minute), all doubts were dispelled; the ranks were closed and the government would never know.

\section{CREATING EFFICIENCY}

Then we had to start squeezing some efficiency out of the main frame. We trained the women to operate the machine and worked behind closed doors for hours a day. The irony was that we started making the computer available by closing the door. No one seemed to complain though. Probably the novelty of actually pressing the wrong buttons yourself had worn off in favour of someone else pressing the right ones. Turn-around time was short. The error rate is down. Why? The keypunch women, with no formal Algol training, even spotted errors in the original coding sheets and correct them while punching.

We started to hire more people. These included (in addition to Knut Skog, today professor at Tromsø) Karl Schjetne from Kjeller, later to take over as director of the centre; Harald Michalsen, later to get his Dr. Techn. on computer-based school timetabling; Nils Høeg from Boeing, later Managing Director of Hydro Data and Fjerndata, and Øivind Solvang also from Boeing, later Managing Director of Guru Papp, now sadly departed; Arnt Otto Østlie, NTH's first candidate to write software for his diploma (and what a fight it was to prise him loose from his NTH institute); Ralph Høibakk, founder of NorData and later Managing Director of Tandberg Data; Tore Bough-Jensen, later to become a senior consultant with Habberstad; Arne Sølvberg, today Professor of Computing at NTH; Olav B. 
Brusdal who kept the machine going, later Assistant Professor at NTH, now also sadly departed, and part-time third shift student operator Kristen Rekdal, later Associate Professor with SINTEF. That was a star-studded team to have stacked around the computer itself. In addition, we had a rapidly growing user group typified by people like Johannes Moe, then Professor at the Division of Marine Structures, later Rektor of NTH and Director of SINTEF, and Øivind Bjørke who combined mechanical engineering with control engineering and who is now Professor of Industrial Automation. There were many others. Once we removed the stopper from the computer djinne-bottle, star performers started pouring out. Starting a computing centre is easy if you make it all available.

Another component of Regnesentret's early success was the course offerings, both to NTH and to the outside world. At NTH some of the older members were a little reluctant to dive in, but the students were very adventurous. In the autumn of 1962 Aimar Sørenssen had already given the very first programming course, but he later left for C.E.R.N. in Switzerland. We now needed a replacement teacher, and I'll never forget my first meeting with Jim Tocher, who came limping out of the lift on crutches, his left leg encased in plaster, his face covered in a red beard years before beards ever hit Norway. Three weeks later, both the cast and the beard disappear. He had just finished a post-doctoral year with Professor Holand and was about to return to Berkeley. I promised him a good job at Boeing if he would stay on six months and do the teaching. Teaching that first year was an utter revelation. Then he moved to stay on at Boeing until retirement.

Actually, there was no place in the timetable for teaching programming, so we announced a spare-time course, three times a week for eight weeks. We expected twenty people to show up; 250 came. When that was over, Knut Skog said that that was it; there would be no further interest this year. "Well let's find out, Knut, and see if it's a waste of time. Let's at least offer the course; if twenty show up, we'll run it." Unbelievably, 150 turned up. "That's absolutely it," says Knut eight weeks later. Me: "Come on, let's try once more." Knut: "Look, I know NTH, you're new here." Me: "There's no harm in asking; if twenty show up, we'll run the course." As we approached the lecture room where the initial meeting was to take place a large crowd had assembled outside the door. "Damn it, they've forgotten to open the door." But no, this is the overflow; 450 people had turned up. One thousand people learn to program the computer during its first year at NTH, all in their spare time. One of the professors complained that the students have deserted his lectures for the computing centre. "They don't even drink any more," he said. "GIER is better than beer," observed Karl Stenstadvold.

Two other courses were available from the start. The first was Brusdal's course on hardware, which became the first ever credit course in computing at NTH. The other was a general awareness course which I gave called 
something like, "How to use the computer" based on years of experience at Boeing. In addition to the internal courses, we started giving courses to practicing engineers, and that became our most successful way of getting new customers.

Another component of availability was the solution to the problem of helping half-trained people write programs while they were learning Algol. Here we experienced a very strange phenomenon indeed. The immediate problem was that soon after we started the first Algol course, Knut Skog found himself inundated with interruptions and could not get anything done. "How do I get out of an infinite loop?", "How can I do complex arithmetic if Algol only deals with real numbers?", "This machine keeps dividing by zero." The usual suspects. We had to hide him, but we also had to answer the questions - we had to make the computer available. Hence, we put together a team of advanced (three-month) users whose job it was to operate a support office during the day. "What shall we call it?" asked Knut. "How about calling it the Oracle service? Keep it going until the summer. That should get it all going."

That was forty years ago, but Oracle still runs today. The most interesting thing is that no one actually runs it. It has been self-perpetuating ever since. Today it consists of some twenty undergraduate and post-grad students; it has no manager and no place in any organisation chart. Whenever people leave, they simply drag in a replacement from around the campus. (Heretical thought: perhaps we only need managers when we wish to perpetuate things that really ought not to be there.) Oracle is very popular amongst its members because they learn far more from other people's mistakes than from their own.

\section{THE NEXT STEPS}

No one anticipated the explosive growth of computing at NTH SINTEF and the probable intention was to have the GIER computer operational on campus through to the 1970s. However, by the end of 1963, we could see GIER would be getting jugged by 1965 , and the long, frustrating process of getting a replacement started already in January, 1964, just a year after we got going. The first step was to get funding from the Department of Education. At first, there was absolutely no question of a new computer for five years. We go down to Oslo loaded with paper and the list of project numbers and titles. Remember, the first thing we ever did in January of 1963 was to set up a seven-digit project number and accounting system. We know very accurately who is doing what on the GIER, and when we open 
our bag and dump our statistics on the official's desk, the day is won. The only question was - how much?

One of the problems that beset us was that there were already two enormous computers in Norway, a Univac 1107 at Norsk Regnesentral in Oslo, and a CDC 3600 at the Atomic Energy Department in Kjeller. We must be compatible with one or the other. To get an IBM computer and present Norway with three incompatible machines would have been an act of inexcusable folly. So which should we get, a 3600 or an 1107 ? Two factors helped us make the decision, one was that we managed to talk Univac into an 1107 for half price, and the other was that the Exec II operating system was admirably suited to large numbers of small jobs, which very much characterised NTH computing at that time. So the 1107 selected itself, but not until after a great deal of marketing effort involving half a dozen computing companies, all of whom had seen the desirability of getting their machine in at NTH, where tomorrow's decision makers were developing their computing edge. That is largely the reason Univac grew so strongly in Norway.

As a postscript, and to demonstrate to today's users that computers did not come quite automatically, when I returned to Boeing the First of May 1965, a telegram was awaiting me from Nils Høeg saying that Univac had cancelled the 1107 because it was half price. A new person had taken over the Univac company-General Baker. He was a tough guy with a new broom, and his first action was to sweep away all unprofitable actions that the company had undertaken. Ours was the most unprofitable. Therefore, I had to go New York, halfway back to Trondheim, to rescue our 1107. As I said at the start, computing was not so much fun anymore. The most fun I ever had, though, was rescuing that 1107 . It's all very well having learned theories about acquiring computers, but it's what goes on behind the scenes that matters. I would like to pay another tribute, this time to General Baker whose fairness and generosity made it possible for NTH to acquire a large, modern computer.

There must be thousands of anecdotes of those times. However, one that is ever vivid in my memory is the way we put one of the Trondheim banks through the wringer. They hired me as a consultant (but not for long). I did not know anything about banks, so I started to find out. To help the process along, I started signing my cheques Charlie Brown, and so did the rest of The Computing Centre. I do not know how many Charlie Brown cheques were cashed, but not a single one was either refused or caught by the auditor's department. Not all problems are computer problems!

We had our frustrations, of course. One thing that people may not be aware of is that the 1107 at Norsk Regenesentral was a world pioneer in remote computing. At one time, there were four terminals simultaneously coupled to it over telephone lines, one in Sweden, our 1104 in Øivind 
Solvang's office, and two others in other parts of Norway. The technical problems were solved, but not the problems Øivind had with the telephone operators! They would listen in suspiciously after two hours of silence, interrupting the data transmission, causing him to start all over again. That brings me to my third debt of gratitude, to Leif Olausen who ran Norsk Regnesentral in those days. His energy, drive, enthusiasm and the tireless way he supported us in Trondheim until we could stand on our own feet deserve our deepest appreciation. He knew how to inspire a bunch of people and get the last ounce of effort out of them. No government working regulation was down there either.

\section{CONCLUSION}

The seed that initiated the Regnesentret crystal was undoubtedly GIER itself. It had a core memory of only $1 \mathrm{~K}$. It was a microcomputer in a broom closet. However, it had two vital properties; it was a highly reliable piece of equipment and it had an excellent compiler-cum-operating system; that is, it was both hardware and software. That was a lesson that the Norwegian computer industry still did not understand a decade later. A computer consists of its software. Had programming been tedious or had productivity been low because of downtime, computing would have got a bad name right from the start. However, Algol is a good language, despite my article in Datamation, January 1963, and, as a result, computing took on like wildfire from the first day. GIER's task was to convince NTH - SINTEF that they needed a computer. No computer that I know of could have achieved that goal more admirably. So by definition, we got the timing right. Had NTH tried starting computing a year earlier, before the compiler was ready, we could not have been able to accomplish anything like such a good start. A software-free computer is no computer.

Those were the good old days, of course. In particular they were noisy mostly laughter. When you tiptoe around current computing departments, all is solemn silence. I suppose they are far more productive than we were, but I doubt whether they work with more enthusiasm, and I hope I don't hurt anyone's feeling if I opine that we worked far longer hours. At any rate, in those days people put in enormous amounts of time and the reason they did so was that it was tremendously fun. We had an esprit de corps. We had a feeling of being wanted.

I would like to end by paying my fourth and last debt of gratitude. Without the unceasing, total, committed support of Karl Stenstadvold, then Director of SINTEF, Regnesentret, NTH, would never have come about. In theory, Regnesentret was impossible, but Karl Stenstadvold was a man who 
made the impossible possible. You can write academic books on management; they aren't worth a row of beans because they aren't written by managers, at least managers of the calibre of Karl. I have known hundreds in my time, but none like him. He's the best of all my memories of Regnesentret, NTH. Sadly, he is no longer with us but we who knew him miss him greatly.

Ending on a note for the computer people of today, the whole point of pioneering anything is to provide following generations with something of value. NTH went from GIER to CRAY in twenty-five years - a factor of 100 million speed-size units in a single human generation - an unimaginable growth. Silicon Graphics machines with 898 processors and the customary array of PCs now surrounds them. NTH has inherited something close to a miracle. I hope they use it well. I hope it was all worth the effort. Despite what I said, I hope it will still be great fun! In the end, we made computing available - the rest was history. 